\title{
Redaktion:
}

Georg Sørensen (ansvarshavende)

Niels Amstrup (anmeldelser)

Jørgen Elklit, Peter Munk Christiansen, Hans-Henrik Holm, Asbjørn Sonnne Nørgaard,

Thomas Pallesen, Niels Chr. Sidenius, Palle Svensson, Lise Togeby

Redaktionssekretær: Anette Juul Hansen

Redaktionskomité:

Peter Bogason, Institut for Samfundsøkonomi og Planlægning, RUC

Thomas Gregersen, Finansministeriet

Morten Kelstrup, Institut for Statskundskab, KU

Poul Erik Mouritzen, Institut for Erhvervsret og Politologi, OU

Ole Fjord Nielsen, Grenå Gymnasium og HF

\section{(C) politica}

Tidsskriftet Politica udgives med støtte fra

Aarhus Universitets Forskningsfond og

Statens Samfundsvidenskabelige Forskningsråd

Omslag: Jørgen Eie Christensen

Sats og tryk: Handy-Print A/S, Skive

ISSN 0105-0710

Redaktionen sluttet d. 20. oktober 1997

Bestilling af tidsskriftet: Se oversigten bagest $\mathrm{i}$ dette nummer.

Manuskripter til Politica kan sendes til nedenstående adresse:

Artikelforslag bedes vedlag abstract.

Interesserede kan rekvirere en skrivevejledning ved henvendelse til:

\section{Redaktøren}

Tidsskriftet Politica

c/o institut for Statskundskab

Universitetsparken

8000 Århus C 